\title{
Üretim İşletmeleri Yöneticilerinin Lojistik Köy Algıları: Karabük İli Örneği ${ }^{1}$
}

\author{
Ahmet Gürbüz ${ }^{a}$, Nurettin Ayaz ${ }^{b^{*}}$, Sevgi Kebecic \\ aKarabük Üniversitesi, İktisadi ve İdari Bilimler Fakültesi, Karabük. \\ ${ }^{\mathrm{b}}$ Karabük Üniversitesi, Safranbolu Turizm Fakültesi, Karabük. \\ cKarabük Üniversitesi, Sosyal Bilimler Enstitüsü, Karabük.
}

\begin{abstract}
$\ddot{O} z$
Üretim işletmelerinde artan dış kaynak kullanımı ile birlikte entegre lojistik faaliyetlerine dayalı yeni hizmet sunumları öne çıkar hale gelmiştir. Taşımacılık kalitesinin artırılması, lojistik maliyetlerin azaltılması, şehir içi trafiğin rahatlatılması, hızl ve güvenli ulaşımının sağlanması gibi amaçları olan lojistik köyler bu süreçte popülerlik kazanmıştır. Kurulduğu bölgenin ekonomik gelişimine ve istihdamına katkı sağlama, çeore ve trafik kirliliğinin önleme, işletmelerin rekabet gücünü artırma gibi faydalar sağlaması bakımından lojistik köyler önem arz eder hale gelmiştir. $B u$ araștırmada hali hazırda bir lojistik köye sahip bulunmayan Karabük ilinde faaliyet gösteren üretim işletmeleri yöneticilerinin lojistik köy algıları ölçülerek, Karabük özelinde lojistik köy boyutunda farkındalık oluşturmak amaçlanmaktadır. Bu amaç doğrultusunda 103 üretim işletmesi yöneticisine anket uygulanmıştır.Araştırma sonuçlarında lojistik köylerin ilde istihdamı ve ihracatı aratacağı, nakliye maliyetlerini düşüreceği yönünde olumlu, ildeki ürünlerin medyatik tanıtımına katkı sağlayacă̆ı yönünde ise olumsuz görüş sergiledikleri tespit edilmiştir. Üretim işletmeleri yöneticilerinin görüşleri kapsamında Karabük ilinde kurulması öngörülen"lojistik köy" için yer önerisi geliştirilmiştir.
\end{abstract}

Anahtar Kelimeler: Lojistik köy, yönetici, algl, Karabük.

\section{The Freight Village Perceptions of the Production Enterprises Managers: The Case of Karabük}

\begin{abstract}
With the increasing of the using of out sourcing in the production enterprises, new service encounters based on integrated logistics activities has become prominent. The freight villages which have the aims of such as; increasing the quality of transport, reducing logistics costs, relieving the city traffic, supporting rapid and safe transportation have gained popularity in this process. The freight villages in terms of the benefits such as; contributing to economic development and employment of the region in which it has been established, preventing environmental and traffic pollution, increasing the competitiveness of the enterprises have become important. In this research, it has been aimed to form awareness at freight village size on the special of Karabuk by measuring freight village perceptions of production enterprises managers which have been operating in Karabuk which have already not had a freight village. In accordance with this purpose, a survey has been conducted to the managers of 108 production enterprises. It has been found in the results of the research that; the production enterprises managers have performed positive opinion on that freight villages will increase employment and
\end{abstract}

1 Bu araştırma, Karabük Üniversitesi Sosyal Bilimler Enstitüsü İşletme Anabilim Dalı “Lojistik Köylerin Pazarlama Sürecine Etkisi: Karabük Özelinde Sektörel Algı Durumu" başlıklı tez çalışmasından üretilmiştir.

*Yazışma adresi.Email: nurettinayaz@karabuk.edu.tr 
export in the city, will reduce the transportation costs, however, they have performed negative opinion on that freight villages will contribute to the mediatic promotion of the products in the city. Within the context of the opinions of the production enterprises managers, it has been developed a place suggestion for the freight village which has been foreseen of establishment in Karabuk.

Keywords: Freigh village, manager, perception, Karabük.

\section{GíRiş}

Hızlı teknolojik gelişmelerin ulusal ve uluslararası pazarlarda ticareti kolaylaştırması, pazardaki rakip işletmelerin arasında ciddi bir rekabet artışına neden olmaktadır. Bu süreçte öne çıkabilen işletmeler; ürünlerini düşük maliyetle, güvenli, kaliteli ve mümkün olan en hızlı bir şekilde nihai tüketiciye ulaştırabilenlerdir. Bu süreçte lojistik köyler; üretim maliyetlerini düşürme, rekabet gücü elde etme ve ürünlerin daha güvenli bir şekilde ulaşımını sağlamada öncülük eden alanlar olarak satın alma, tedarik, taşımacılık ve dağıtım, depolama,müşteri hizmetleri, talep planlama, sipariş yönetimi, malzeme ve envanter yönetimi, ambalajlama, paketleme, satış sonrası hizmetler, malzeme aktarımı, trafik yönetimi gibi faaliyetlerle üretim işletmeleri düzeyinde popülerlik kazanmıştır. Özellikle, üretim ve hizmet sektörlerinde artan dış kaynak kullanımı entegre lojistik faaliyetlere dayalı yeni hizmet sunumlarını öne çıkarır hale gelmiştir (Özgen, 2011; Elgün ve Elitaş, 2011; Vural ve Tuna, 2014).

$\mathrm{Bu}$ araştırmada; demir ve çelik üretimi ile öne çıkan Karabük ilinde üretim işletmeleri yöneticilerinin lojistik köylerin pazarlama sürecine etkisine yönelik algılarının ortaya çıkarılması ve Karabük ilinde lojistik köyler konusunda farkındalık oluşturmak amaçlanmaktadır. Ayrıca Karabük'te kurulması öngörülen lojistik köyü için yer önerisi yapılan ilk çalışma olması sebebiyle önem arz etmektedir. Elverişli coğrafi mekânlara sahip Türkiye'de bu konudaki çalışmaların artması, lojistik köy ve pazarlama kapsamına giren faaliyetlerin etkin bir şekilde gerçekleştirilmesi, rekabetin yoğun yaşandığı küreselleşen dünyada avantaj üstünlüğü sağlayabilecektir.Bu amaçla Karabük ilinde 103 üretim işletmesi yöneticisine anket uygulanmış, çalışmada yönetici görüşleri perspektifinden Karabük iline yönelik lojistik köy için yer önerisi geliştirilmiştir.

\section{LITERATÜR}

Artan teknolojik gelişmeler ve rekabet baskısı altında işletmelerin mevcut durumlarını koruyarak veya daha verimli yatırımlar yaparak karlılıklarını artırmaları, işletmelerin maliyetlerini yönetme ve kontrol altında tutabilme başarısı ile mümkündür. Ürünlerin nihai tüketiciye ulaştırılması sürecinde işletmeler için en önemli maliyetlerin başında toplam lojistik maliyetleri gelmektedir. Bu sorunun önemi küçük bir köy haline gelen dünyadaki ticari akış hızının artmasına bağlı olarak lojistik köylerin oluşmasına neden olmuştur (Bezirci ve Dündar, 2011: 293).

Lojistik köyler basitçe lojistik akışların ve lojistikle ilgili her kapsamdaki operasyonların (dağıtım, stoklama, taşıma, konsolidasyon, ambalajlama, gümrük işlemleri, ithalatlar, ihracatlar, transit işlemler, altyapısal servisler, sigorta, bankacılık ve benzeri pazarlama faaliyetleri) uygulandığı noktalardır. Trafik akışlarının düğüm 
noktaları olan lojistik köyler; çok çeşitli operasyonları gerçekleştirmek üzere ticari işletmelerin taşıma, lojistik ve dağıtımla ilgili olarak yaptıkları tüm faaliyetlerin bir arada olduğu yerel, bölgesel ya da küresel bölgelerden oluşabilirler. Dünya ticaretindeki büyüme, üretimin küreselleşmesi, malların kullanıcıya ulaştırılmasında zamanın önemi, taşıma, depolama ve dağıtım merkezlerinin yönetimi konuları yanı sıra katma değer hizmetleri, tedarik hizmetleri, gümrükleme hizmetleri, depo yönetimi, paketleme, elleçleme, etiketleme, dış ticaret ve sigorta danışmanlık hizmetleri de lojistik köy hizmetlerine dahil edilir hale gelmiş ve bu köylere olan ilgiyi artırmıştır (Aydın ve Öğüt, 2010).

Lojistik köyler, yük dağıtım demetlerinin fonksiyonel bir şekilde bütünleşmesini ve şehir çevresinde dağınık halde bulunan dağıtım merkezlerinin karayoluna yakın olan alanlarda yerleşimlerini öngören alanlardır (Paksoy, 2011: 10).Çeşitli ülkelerde farklı isimlerle (lojistik üs, yük köyü, lojistik merkez, lojistik alan, lojistik park, dağıtım merkezi) çağırılan lojistik köylerin temel kuruluş amaçları; depolama, bakım-onarım, yükleme-boşaltma, elleçleme, tartı, yükleri bölme, birleştirme, paketleme vb. faaliyetlerini gerçekleştirme, imkânları olan ve taşıma modları arasında düşük maliyetli, hızlı, güvenli, aktarmaktır (Koldemir ve Kudu, 2015).

Lojistik köyler, çoklu tedarik zincirleri sağlayan, birçok taşıma moduna kendi çoklu bağlantıları tarafından karakterize edilirler. Bu nedenle, farklı taşıma modları arasında aktarmalara izin vermek için etkin çalıştırma sistemi sağlamalıdır. Çoklu bağlantıları nedeniyle, lojistik köyler temel olarak; tedarik zinciri elemanlarının taşıma şartlarında performansını geliştirmek için tedarik ve dağıtım lojistikleri bağlantısına uygun bir ara yüzdür (Elgün ve Elitaş, 2011: 631).

Lojistik sektörünün bir bölgede geliştirilmesi ve erişebilirliğinin artırılması, daha geniş bir işgücü pazarına erişim imkânı, tedarikçiler ve müşterilere daha hızlı ve ucuza ulaşılması, pazar alanının genişlemesi ve arazi kullanımı ile ilgili kısıtların kaldırılmasına olanak oluşturur (http://www.kto.org.tr).

Lojistik köylerde taşımacılık, intermodal faaliyetler ve lojistik faaliyetlere odaklanır ve bu merkezler genellikle metropol bölgelerin dışında kalan, farklı taşıma türleri bağlantılarına yakın olan bölgelerden seçilir. Lojistik köylerde nakliye ve lojistikle ilgili faaliyetleri gerçekleştiren işleticiler, inşa edilen binaların sahibi ya da kiracıları olabilmekteler. Ayrıca serbest rekabet kuralları doğrultusunda bir lojistik köyünün her firmanın ilgili tüm faaliyetlerle iştigal edebilmesine olanak sağlaması ve bu işlemlerin gerçekleştirilmesi için gereken tüm kamusal tesislerle donatılmış olması öngörülür. Lojistik köyler, bir yandan kentlerdeki trafik tıkanıklığı sorununun çözülmesi, diğer yandan da yük taşımaların verimliliğinin artırılmasına yönelik pratik çözümler sunar. Özellikle şehir içinde, karayolu araçlarının daha az yol alması ile hava kirliliğinde azalma sağlar (Özgen, 2011: 6).

Lojistik köyler; lojistik merkez, lojistik üs olarak da adlandırılmakta ve çok yönlü ulaşım ağlarını içeren lojistik bölgeler olarak tanımlanmaktadır. Burada, lojistik köy tanımının lojistik merkez tanımına çok yakın olduğu anlaşılmaktadır. Hatta birçok 
yerde aynı anlamda kullanılmaktadır. Halbuki çok ufak bir fark vardır. Lojistik merkezler, tek ve yansız yasal, yani, kurumsal bir yapıdır. Lojistik köyler ise, yine tek, ama, özel ya da halka açık yapılardır (Elgün, 2011: 205).Farklı yöneticiler tarafından idare edilen lojistik ve dağıtım, yerel ve uluslararası taşımacılığı içeren kargo taşımacılığına ilişkin tüm aktiviteleri kapsayan bölge olan lojistik köyler "Intermodal terminaller", "Kara için merkezler", "Freight Villages", "Logistics Campuses", "Plates Forms Logistics", "Commercial Center", "Dry Ports", "Interporto" adını alırlar (Erdil, 2010: 55).

Lojistik köylerde tek bir taşıma türü ile hizmet görülebilmesi söz konusu olabilir. Ancak, çok türlü taşımalara olanak veren tesisler, küresel ve bölgesel pazarlara doğrudan erişim olanağı sağlamaktadır. Eşya elleçlemelerinde çok türlü taşımaların teşvik edilmesi için bir lojistik köyüne birden fazla taşıma türüyle hizmet verilmesi tercih edilmektedir (karayolu, demiryolu, denizyolu ve iç suyolları). Lojistik köylerin geliştirilmesi, birbiriyle doğrudan bağlantısı olmayan birtakım kullanıcılar (ayrı sektörlerden gelen kuruluşlar) tarafından gerçekleştirilen eşya hareketlerinin bir ölçek ekonomisi kapsamında yönetilmesi açısından önemli faydalar getirmektedir. Zira bu kullanıcılar, büyük kısmı bir ulaşım terminali etrafında bulunan aynı tesisleri ve donanımları kullanmaktadır. Böylelikle, taşıma maliyetleri düşmekte, taşımaların güvenilirliği ve sağlıklı gerçekleşmesi sağlanmaktadır. Bu durum, lojistik köyün kullanıcılara sağladığı en önemli faydadır (Aydın ve Öğüt, 2010: 7).

Çok iyi planlanmış ve yük taşımacılığıyla ilişkili tüm faaliyetlerin en iyi şekilde yönetildiği bir lojistik köyün sağladığı faydalar şu şekilde özetlenmektedir (Paksoy, 2011: 52):

- Yük taşımalarıyla ilgili ticari faaliyetlerin bir araya toplanması suretiyle lojistik zincirin en mükemmel hizmet sunabilmesi,

- Araç (özellikle kamyon ve tır), depo, insan gücü kullanımının en uygun hale getirilebilmesi,

- Tüm faaliyetler için güvenli bir ortam/çevrenin yaratılabilmesi,

- Tek merkezden yönetim oluşturulabilmesi,

- Tek elden planlama yapılabilmesi,

- Toplam nakliye, sinai ve personel maliyetlerinde düşüşs sağlanabilmesi,

- Taşıma cirolarının artırılabilmesi,

- Kaliteli çalışma ortamı sağlanabilmesi,

- Destekleyici hizmetler sunabilmesi.

Bir lojistik köyden beklenen faydaların elde edilebilmesi için verilen servis hizmetlerinin çeşitlilik arz etmesi ve nitelikli olması gerekmektedir. Genellikle lojistik merkezlerde sunulan servis hizmetleri şunlardır: depo ve tesisler, gümrük hizmetleri, banka, postane, kargo ve sigorta firmaları, sosyal, eğitim ve sağlık tesisleri, güvenlik hizmetleri, hukuk büroları, kamuya açık telefon, toplu taşıma ile ulaşım altyapısı, yükleme ve boşaltma işlemleri için yerleri ve park alanlarıdır (Özgen, 2011: 7). Oteller, lokanta ve kafeteryalar, araç bakım ve onarım merkezleri, yakıt ikmal istasyonları ve araba yıkama yerleridir (Kılıç vd., 2009: 10). Bu özelliklere sahip olan bir lojistik köy 
her türlü servis hizmetlerini sunabildiği gibi, lojistik köyün yönetimini, hatta, bu köyde bulunan firmaların da işlerini kolaylaştıracak.

Hemen hemen bütün lojistik köyler bünyelerinde intermodal ve multimodal terminalleri bulundururlar. Bilindiği gibi intermodal taşımacılık, ürünlerin aynı taşıma birimi içinde herhangi bir müdahalede bulunulmaksızın birden fazla taşıma birimiyle taşınmasıdır. Bu nedenle, aktarma merkezi olarak da hizmet veren lojistik köylerde bu aktarımların yapılabilmesini sağlayan terminaller kurulur. Diğer taraftan multimodal taşımacılık daha genel bir kavramdır. En az iki farklı taşıma yöntemiyle, demiryolu ve karayolu ile taşınan ürünlerin limanda birleştirilmesi veya ayrıştırılarak taşınması multimodal taşımacılıktır. Kombine taşımacılıkta ise taşıma birimi içinde bulunan yükün yeniden yüklemeye gerek kalmadan farklı taşıma birimleriyle taşınması söz konusudur. Ro-Ro gemisine yüklenen kamyonlar veya vagonlardaki yüklerin vagonlarla beraber gemiyle taşınması bir kombine taşımacılığıdır.

Lojistik köyde verilen hizmeti kolaylaştıran diğer önemli bir faktör de teknik hizmetlerin varlığıdır. Bu teknik hizmetlerin büyük bir kısmı lojistik köyün kuruluş aşamasında yani fiziksel altyapının oluşturulması sürecinde planlanır ve oluşturulur. Bunların önemi lojistik köyün hizmete girmesinden sonra daha çok anlaşılır. Nitekim, birden fazla taşıma türü, tek merkezden dağıtım, akıllı depolama sistemleri, katma değerli üretim ve imalat işlemelerin varlığı, gümrük işlemleri gibi özellikler bir lojistik köye işlerlik kazandıracak ve bu köyün sunduğu faydaları maksimum dereceye çıaracaktır (Üzülmez, 2008: 14).

Günümüzde uygun fiziksel özelliklere sahip lojistik köylerin sayısı giderek artmaktadır. Fiziksel özellikler lojistik köyün ulusal ve uluslararası önemini artırır. Bir lojistik köyün en az 250 hektar yüzölçümü olması, bir metropolün içinde ya da yakınında bulunması, karayoluyla ulaşım imkânına ve demir yolu bağlantılarına sahip olması, çok modlu taşıma tesislerine, limanlara, iç suyollarına ve havaalanlarına yakınlığıyla doğrudan erişim imkânı sunması, planlı ve imarı gelişmeye uygun modern ofisler ve binalar ile gelişmiş iletişim ve bilgi teknolojisi altyapısına sahip olması gibi özellikler bir lojistik köyde bulunması gereken fiziksel özellikler olarak kabul edilmektedir (Elgün, 2011: 210).

Belli noktalarda toplanmış firmalar için bir maliyet avantajı ve bağlantılı olarak da rekabet avantajı sağlama düşüncesiyle kurulan lojistik köyler için uzun vadeli bir planın yapılması gereklidir (Elgün, 2011: 212). Lojistik köyün yerinin belirlenmesi lojistik köylerin kurulmasında önemli bir adımdır. Farklı taşımacılık modlarının aynı anda kullanılabilme imkânları yer seçimini öncelikli etkileyen kriterdir. Seçilecek yerin demiryolu, karayolu, havayolu ve denizyolu bağlantılarının olmasına dikkat edilmelidir. İsabetli bir karar için farklı seçim kriterleri göz önünde bulundurularak lojistik köy kurulması için en uygun kararın alınması gerekir (Elgün ve Elitaş, 2011: 631).

Ulaşım imkânları, lojstik köylerin kuruluş yeri seçiminde ve sosyal ve ekonomik gelişiminde öne çıkan durumdur. Ekonomik aktivitelerin kuruluş yeri, arazisinin uygunluğuna bağlıdır. Kuruluş yerinin görülebilirliği, sunduğu hayat 
kalitesi, lokal ulaştırma modlarına sahipliği gibi konum özellikleri önemlidir. Ayrıca, işgücü (ücretler, kalifiye eleman bulabilme), materyaller (genel olarak hammaddeler), enerji, lokal, bölgesel ve global pazarlar, tedarikçilere ve tüketicilere, politik birimlere (ulusal, bölgesel, mekansal) olan yakınlık gibi ulaşılabilirlik seviyesi de önem arz etmektedir. Hukuki olarak devlet destekleri, kanunlar, vergileme sistemi de kuruluş yeri seçiminde önemlidir. Bir lojistik köy için yer seçiminde, lojistik ağın yapısı ve yoğunluğu nihai belirleyici öğelerdir (Özgen, 2011: 5).

Lojistik köyün bulunduğu alan, ülkenin, bölgenin ve hatta yerel pazarın mevcut durumu ve gelecekteki eğilimleri ve taleplerini karşılayacak şekilde büyümeye olanak verecek bir konumda olmalıdır. Zira lojistik köyün işletilmesi sırasında ortaya çıkan en önemli sorun, lojistik köyün planlanması aşamasındaki alan büyüklügü hakkında yapılan araştırmaların yetersiz ya da yanlış oluşundan kaynaklanmaktadır. Yine, normal şartlarda, sağlıklı bir şekilde büyüyen lojistik köyün işletilmesi sırasında, büyüme alanının bulunmaması, yükün türüne hizmet edemeyip pazar talebini karşılayamaması ve o pazarı kaybetmesi gibi sorunları ortaya çıkaracaktır. Lojistik köyün yeri seçilirken yine bu alanın birçok olanağı yerine getireceği düşünülmeli; buna göre pazara yakınlık, erişebilirlik, operasyon sürelerinin ve maliyetlerinin azaltılması, şehirde açacağı kirlilik ve tıkanıklık ile şehrin yaşam kalitesinde nasıl etkileneceği göz önüne alınmalıdır (Erdil, 2010: 85).

Lojistik köylerin bir diğer özelliği de yönetim özellikleridir. Lojistik köylerde yönetim; kamu, özel ve kamu-özel sektör ortaklığı olmak üzere üç farklı şekilde görülebilmektedir. Ancak, günümüzde en yaygını birçok lojistik köyde uygulanan "kamu-özel sektör ortaklığı" modelidir. Bu modelde sermaye yapısı kamu-özel sektör tarafından karşılanır. Ancak, kamu genellikle sermayenin ana hissedarıdır. Kamu-özel sektör ortaklığı modelinin seçilmesindeki en önemli sebep, kamu otoritesinin gerekliliğinin yanı sıra, mali yapı ve planlama ile de ilgilidir. Bilindiği gibi, lojistik köy yatırımları uzun vadeli yatırımlar olduğundan ilk etapta özel sektör için cazip olmamaktadır. Bu yüzden kamunun mali destek sağlama gücü daha yüksek olduğundan lojistik köylerin yönetiminde kamu-özel sektör ortaklığ1 tercih edilmektedir (Kaynak ve Zeybek, 2007: 48).

\section{YÖNTEM}

$\mathrm{Bu}$ araştırmada Karabük ilinde faaliyet gösteren üretim işletmeleri yöneticilerinin tanımlayıcı bilgileri ile lojistik köy algıları arasındaki ilişki ölçülmektedir. Bu kapsamda amaçlarına göre araştırma tiplerinden olan betimleyici araştırma tipi kullanılmıştır. Araştırma amaçlarını değerlendirmek için lojistik köyün pazarlama sürecine etkisine ilişkin sorulardan türetilen hipotez çiftlerinden araştırmacının beklentilerine uygun olan hipotezleri aşağıdaki gibidir:

- H1: Üretim işletmeleri yöneticilerinin cinsiyetine göre lojistik köy algısı arasında anlamlı bir farklılık vardır.

- $\mathrm{H}_{2}$ : Üretim işletmeleri yöneticilerinin yaşına göre lojistik köy algısı arasında anlamlı bir farklılık vardır. 
- $\mathrm{H}_{3}$ : Üretim işletmeleri yöneticilerinin eğitim durumuna göre lojistik köy algısı arasında anlamlı bir farklılık vardır.

- $\mathrm{H}_{4}$ : Üretim işletmeleri yöneticilerinin çalıştı̆̆1 sektöre göre lojistik köy algısı arasında anlamlı bir farklılık vardır.

- H5: Üretim işletmeleri yöneticilerinin yöneticilik pozisyonuna göre lojistik köy algısı arasında anlamlı bir farklılık vardır.

\section{Araştırma Alanı}

Karadeniz Bölgesi'nin Batı Karadeniz Bölümü'nde yer alan Karabük, kuzeyde Bartın, kuzeydoğu ve doğuda Kastamonu, güneydoğuda Çankırı, güneybatıda Bolu, batıda ise Zonguldak illeri ile komşudur. Karabük'ün yüzölçümü 4.109 km²'dir. Karabük, Ankara'ya 217 km., İstanbul'a 395 km., Bolu'ya 132 km., Çankırı'ya 195 km., Kastamonu'ya 125 km., Bartın'a 87 km. ve Zonguldak'a 110 km. uzaklıktadır.1941 yılında Safranbolu ilçesine bağlı bucak olan Karabük 3 Mart 1953 tarihinde 6068 sayılı kanunla Zonguldak İline bağlı bir ilçe haline gelmiştir. 6 Haziran 1995 gün ve 22305 sayılı Resmi Gazetede yayımlanan 550 sayılı Kanun Hükmünde Kararname ile Çankırı'dan; Ovacık ve Eskipazar ilçeleri ile Zonguldak'tan; Eflani, Safranbolu ve Yenice ilçelerinin birleştirilmesiyle Türkiye'nin $78 . \quad$ İli olmuştur (http://karabukyatırım.com/).

Karabük, hem işlek karayollarına yakın hem de demiryolu üzerinde yer alan bir ildir. İlimizde 182 km.si devlet yolu, 178 km'si il yolu olmak üzere $360 \mathrm{~km}$. karayolu bulunmaktadır. Karabük, Çankırı-Zonguldak demiryolunun 293.km'sinde yer almaktadır. Bu demiryolu üzerinde Türkiye Cumhuriyeti Devlet Demiryolları (TCDD)'nın Gar ve İstasyon Müdürlükleri ile lojistik müdürlükleri gibi birimler yer almaktadır (Gürbüz, 2009: 11). Karabük'te demir yolu ağının bulunması bir avantaj olmakla birlikte özellikle yolcu taşımacılığ Uzunluğu 415 km'yi bulan Irmak-Karabük-Zonguldak (IKZ) demiryolu hattının 189 km’lik kısmı bölge içinde bulunmaktadır. Bölgede demiryolu sadece ZonguldakKarabük-Çankırı-Irmak arasında tek hat olarak mevcuttur. Bölge içinde en yaygın demiryolu ağının Karabük'te bulunduğu görülmektedir. Bunun sebebi, Türkiye'nin ilk ağır sanayi tesislerinden Karabük Demir-Çelik Fabrikası'nın kurulmasından sonra hammadde ve kömür temini için demiryolu yatırımlarına öncelik verilmiş olmasıdır. 25 Ocak 2012 tarihinde başlanan ıslah çalışmaları kapsamındaki projenin toplam süresi 48 aydır. Ülkü-Karabük-Zonguldak arası mesafenin ilk 24 aylık sürede tamamlanması öngörülmüştür. Projeyle birlikte mevcut hatların $A B$ standartlarında tren işletmeciliğine uygun hale getirilmesi planlanmaktadır (http://bakka.gov.tr).

Karabük, kuruluşu itibariyle ekonomisi sanayiye dayalı bir ildir. 3 Nisan 1937 yılında ilk Entegre Demir Çelik üretim tesislerinin temelinin atılması ve zaman içerisinde özel sektör tarafından kurulan haddehanelerin üretimleriyle birlikte Demir Çelik sektörü lokomotif sektör konumundadır. Karabük'te Demir Çelik sektörünün varlığı Malatya, Sivas, Kastamonu, Ankara, Bartın, Zonguldak, Bolu, Çankırı, Kayseri gibi illerin yer aldığı bölgeyi de ekonomik olarak doğrudan etkilemektedir. 


\section{Araştırma Evreni ve Örneklem}

Araştırmanın evreni Karabük'te faaliyet gösteren üretim işletmeleri yöneticileri oluşturmaktadır. Karabük Sanayi ve Ticaret Odası'na kayıtlı 108 ve Safranbolu Sanayi ve Ticaret Odası'na kayıtlı 35 adet imalat yapan işletme olduğu her iki kurumdan alınan bilgiler doğrultusunda tespit edilmiştir. Araştırmada bir ihtimalli örnekleme yöntemi olan basit tesadüfi (rassal) örnekleme yöntemiyle katılımcılar seçilmiştir. Araştırmanın yapıldığı Nisan 2015 yılında Karabük Sanayi ve Ticaret Odası'na ve Safranbolu Sanayi ve Ticaret Odası'na bağlı 143 üretim işletmesinin kayıtlı olduğu tespit edilmiştir. Araştırma örnekleminin, \%95 güven aralığında temsilci yeteneğine sahip 104 işletme olduğu tespit edilmiştir. Bu kapsamda araştırmada 108 işletme yöneticisine anket uygulanmış ve bu anketlerin tamamı değerlendirmeye alınmıştır.

\section{Araştırma Verilerinin Toplaması}

Karabük'te faaliyet gösteren üretim işletmelerinin lojistik köy algılarının araştırıldığ1 bu çalışmada, öncelikle ilgili yazın taranarak, kuramsal çerçeve oluşturulmuştur. İkici aşamada uygulama çalışması kapsamında, araştırma amacına ulaşmak için, Karabük Ticaret ve Sanayi Odası'na ve Safranbolu Ticaret ve Sanayi Odası'na kayıtlı üretim işletmeleri yöneticilerine yüz yüze görüşme şeklinde anket uygulanmıştır.Araştırmada kullanılan anket üç bölümden oluşturulmuştur. Anketin ilk bölümünde, katılımcıların demografik (cinsiyet, yaş, eğitim durumu) ve diğer özelliklerinin (çalıştığı sektör, yöneticilik kademesi, lojistik köy bilgisi) belirlemesinde sınıflama, lojistik köy algılarının belirlenmesinde aralıklı ölçek kullanılmıştır.Aralıklı ölçek sorularında 5'li Likert (Hiç Katılmıyorum, Az Katılıyorum, Orta Düzeyde Katılıyorum, Çok Katılıyorum, Tamamen Katılıyorum) kullanılmış, katılımcılardan kendileri için en uygun olan seçeneği işaretlemeleri istenmiştir. Üretim işletmeleri yöneticilerinin lojistik köylere yönelik algılarının belirlemesi kapsamında toplam 35 soru sorulmuştur.

\section{Araştırma Verilerinin Analizi}

Üretim işletmelerin lojistik köy algılarının araştırıldığı bu çalışmadan elde edilen veriler, istatistik paket programı (SPSS 20) kullanılarak analiz edilmiştir. Anketler cevaplandırıldıktan sonra ankette yer alan önermelerin güvenilirliği "Cronbach Alpha" ile test edilmiş ve güvenilirlik katsayısı $(\alpha) 0,994$ olarak belirlenmiştir.

Araştırma verilerinin analizi kapsamında ilk olarak araştırma örnekleminin demografik özelliklerini belirlemek amacıyla frekans ve yüzde dağılımları tespit edilmiştir. İkinci aşamada, işletmelerin lojistik köy algılarına ilişkin önermelerin aritmetik ortalama ve standart sapma değerleri analiz edilmiştir. Üçüncü aşamada, iki örneklem gurubu arasında ortalamalar açısından fark olup olmadığını belirlemek amacıyla "t testi" ve ikiden çok örneklem arasında ortalamalar açısından fark olup olmadığını tespit etmek amacıyla "Varyans Analizi (ANOVA)" uygulanmıştır. 


\section{BULGULAR}

Karabük ili içerisinde lojistik köy kurulmasına yönelik olarak sektör yöneticilerinin algılarını belirlemek amacıyla gerçekleştirilen araştırmaya katılan yöneticilerin demografik özelliklerine (cinsiyet, yaş, eğitim durumu) ve diğer özelliklerine (çalıştığı sektör, yöneticilik pozisyonu, lojistik köy bilgisi, lojistik köy yeri önerine katılım durumu) yönelik frekans ve yüzde dağılımı Tablo 1'de yer almaktadır:

Tablo 1. Katılımcıların Demografik ve Diğer Özelliklerine İlişkin Bilgiler (n=108)

\begin{tabular}{|c|c|c|c|}
\hline Değişkenler & Gruplar & $f$ & $\%$ \\
\hline \multirow{2}{*}{ Cinsiyet } & Erkek & 93 & 86,1 \\
\hline & Kadın & 15 & 13,9 \\
\hline \multirow{4}{*}{ Yaş } & $31-35$ yaş & 7 & 6,5 \\
\hline & $36-40$ yaş & 33 & 30,6 \\
\hline & $41-45$ yaş & 51 & 47,2 \\
\hline & 46 ve üzeri & 17 & 15,7 \\
\hline \multirow{6}{*}{ Eğitim Durumu } & İlkokul & 16 & 14,8 \\
\hline & Ortaokul & 8 & 7,4 \\
\hline & Lise & 43 & 39,8 \\
\hline & Ön Lisans & 13 & 12,0 \\
\hline & Lisans & 24 & 22,2 \\
\hline & Lisansüstü & 4 & 3,7 \\
\hline \multirow{5}{*}{ Çalıştığ1 Sektör } & Demir ve Çelik & 44 & 40,7 \\
\hline & Orman ve Ağaç & 7 & 6,5 \\
\hline & Tekstil & 13 & 12,0 \\
\hline & Gida & 28 & 25,9 \\
\hline & Diğer & 16 & 14,8 \\
\hline \multirow{3}{*}{ Yöneticilik Pozisyonu } & Üst kademe yönetici & 47 & 43,5 \\
\hline & $\begin{array}{l}\text { Orta kademe } \\
\text { yönetici }\end{array}$ & 56 & 51,9 \\
\hline & Alt kademe yönetici & 5 & 4,6 \\
\hline \multirow{2}{*}{ Lojistik Köy Bilgisi } & Evet & 70 & 64,8 \\
\hline & Hayır & 38 & 35,2 \\
\hline \multirow{2}{*}{$\begin{array}{l}\text { Lojistik Köy Yeri Önerisine } \\
\text { Katılım Durumu }\end{array}$} & Evet & 77 & 71,3 \\
\hline & Hayır & 31 & 28,7 \\
\hline
\end{tabular}

Tablo 1'de görüldüğü üzere araştırma katılımcılarının \%86,1'i erkek, \%13,9'u kadındır. Yöneticilerin yaş oranları incelendiğinde; \%47,2 sinin 41-45 yaş aralığında olduğu görülmektedir. Araştırmaya katılanların eğitim durumları incelendiğinde, ankete katılan 108 kişiden 43'ünün lise, 24'ünün lisans, 16'sının ilkokul, 13'ünün ön lisans,8'inin ortaokul ve $4^{\prime}$ ünün lisansüstü mezuniyete sahip bulundukları tespit edilmiştir. Katılımcıların çalıştıkları sektör dağılımında \%40,7'si demir ve çelik, \%25,9'u gıda öne çıkmaktadır. Katılımcılardan 47'si üst kademe, 56'sı orta kademe ve 5'i alt kademe yönetici pozisyonunda çalışmaktadır. 108 yöneticiden 70'inin $(\% 64,8)$ lojistik köy ile ilgili bilgi sahibi olduğu, 38'inin(\%35,2) bilgi sahibi olmadığ ${ }^{\prime}$ saptanmıştır. Araştırma kapsamında yöneticilere lojistik köy yeri olarak önerilen Eskipazar İlçesi 
Bayındır Köyü ile ilgili olarak yöneticilerin \%71,3'üuygun, \%28,7'si uygun bulmadı̆̆ şeklinde görüş belirtmektedir.

Üretim işletmeleri yöneticilerinin lojistik köy algılarını ortaya çıkarılmasına ilişkin önermeler ve bu önermelerin genel aritmetik ortalaması ile yöneticilerin demografik ve diğer özelliklerine arasında \%5 güven aralığında ( $p<0,05$ anlamlılık düzeyinde) anlamlı bir farklılık bulunup bulunmadığını tespit etmekiçin gerçekleştirilen $t$ testi ve Varyans Analizi (ANOVA) sonuçları Tablo 2, Tablo 3 ve Tablo 4 'te verilmiştir.

\section{Tablo 2. Üretim İşletmeleri Yöneticilerinin Lojistik Köy Algılarının Belirlenmesine Yönelik Önermeler}

\begin{tabular}{|c|c|c|}
\hline Önerme & $\bar{x}$ & s.s. \\
\hline Lojistik köyler ilimizde istihdam edilen personel sayısını artıracaktır. & 3,23 & 1,49 \\
\hline Lojistik köyler müşteri memnuniyetini artıracaktır. & 3,18 & 2,25 \\
\hline Lojistik köyler ilimizdeki vergi gelirlerini artıracaktır. & 3,15 & 1,43 \\
\hline Lojistik köyler ihracatı artıracaktır. & 3,14 & 1,43 \\
\hline Lojistik köyler nakliye maliyetlerini düşürecektir. & 3,13 & 1,5 \\
\hline Lojistik köyler karayolundaki trafik yükünü azaltacaktır. & 3,11 & 1,50 \\
\hline Lojistik köyler işletmelere rekabet avantajı sağlayacaktır. & 3,07 & 1,38 \\
\hline Lojistik köyler çevre kirliliğini azaltacaktır. & 3,07 & 1,51 \\
\hline Lojistik köyler demiryolu ulaşımını geliştirecektir. & 3,04 & 1,49 \\
\hline Lojistik köyler pazarlara ulaşım maliyetlerini düşürecektir. & 3,03 & 1,45 \\
\hline Lojistik köyler gümrük kolaylığı sağlayacaktır. & 3,01 & 1,47 \\
\hline Lojistik köyler, ürünlerin pazarlamasında avantaj sağlayacaktır. & 2,99 & 1,32 \\
\hline Lojistik köyler, firmaların karlılığını artıracaktır. & 2,97 & 1,34 \\
\hline Lojistik köyler,üretim maliyetlerinin düşmesine yardımcı olacaktır. & 2,96 & 1,31 \\
\hline Lojistik köyler yeni pazarlama alanları oluşturacaktır. & 2,96 & 1,35 \\
\hline Lojistik köyler müşterilerle olan ilişkileri geliştirir. & 2,95 & 1,31 \\
\hline $\begin{array}{l}\text { Lojistik köyler, ilimizdeki ürünlerin hedef pazarlara güvenli ulaşımını } \\
\text { sağlayacaktır. }\end{array}$ & 2,94 & 1,33 \\
\hline Lojistik köyler, ilimizin dış dünyaya tanıtımını sağlayacaktır. & 2,94 & 1,39 \\
\hline Lojistik köyler, ilimizdeki ürünlerin hedef pazarlara hızlı ulaşımını sağlayacaktır. & 2,92 & 1,30 \\
\hline Lojistik köyler yenilikçiliği artıracaktır. & 2,90 & 1,30 \\
\hline Lojistik köyler bakım-onarım kolaylığı sağlayacaktır. & 2,90 & 1,41 \\
\hline Lojistik köyler depolama kolaylığı sağlayacaktır. & 2,89 & 1,41 \\
\hline Lojistik köyler danışmanlık kolaylığı sağlayacaktır. & 2,87 & 1,45 \\
\hline Lojistik köyler ilimizdeki üretim miktarını artıracaktır. & 2,86 & 1,35 \\
\hline $\begin{array}{l}\text { Lojistik köyler, ilimizdeki sanayi dışındaki diğer sektörlerin de gelişimine sinerji } \\
\text { oluşturacaktır. }\end{array}$ & 2,86 & 1,31 \\
\hline Lojistik köyler sigortalama kolaylığı sağlayacaktır. & 2,84 & 1,41 \\
\hline Lojistik köyler girişimciliği teşvik edecektir. & 2,82 & 1,26 \\
\hline Lojistik köyler işletmelerin kurumsallaşmasına yardımcı olacaktır. & 2,79 & 1,37 \\
\hline Lojistik köyler işletmeler arasında işbirliğini geliştirecektir. & 2,75 & 1,31 \\
\hline Lojistik köyler yeni üretim alanları oluşturacaktır. & 2,69 & 1,24 \\
\hline Lojistik köyler farklı ilçeler arasında işbirliğini geliştirecektir. & 2,65 & 1,24 \\
\hline Lojistik köyler ildeki altyapının gelişimine destek sağlayacaktır. & 2,65 & 1,29 \\
\hline
\end{tabular}


Tablo 2. Üretim İşletmeleri Yöneticilerinin Lojistik Köy Algılarının Belirlenmesine Yönelik Önermeler (Devamı)

\begin{tabular}{|l|c|c|}
\hline Önerme & $\bar{x}$ & s.s. \\
\hline Lojistik köyler işletmeler arasında ortak çalışmayı teşvik edecektir. & 2,62 & 1,28 \\
\hline Lojistik köyler, ilimizdeki ürünlerin medyatik tanıtımını sağlayacaktır. & 2,61 & 1,29 \\
\hline Lojistik köyler KOBİ niteliğindeki işletmelere dezavantaj oluşturacaktır. & 2,25 & 1,23 \\
\hline Genel Aritmetik Ortalama & $\mathbf{2 , 9 1}$ & - \\
\hline
\end{tabular}

Tablo 2'de verilen üretim işletmeleri yöneticilerinin lojistik köy algılarını ortaya çıkarılmasına ilişkin önermeler kapsamında yöneticilerin en çok duyarlılık gösterdiği önermeler; "lojistik köyler ilimizde istihdam edilen personel sayısını artıracaktır"( $\bar{x}=3,23)$, "lojistik köyler müşteri memnuniyetini artıracaktır" $(\bar{x}=3,18)$ ve "lojistik köyler ilimizdeki vergi gelirlerini artıracaktır" $(\bar{x}=3,15)$ olmuştur. Üretim işletmeleri yöneticilerinin en az katılım gösterdiği önermeler ise "lojistik köyler işletmeler arasında ortak çalışmayı teşvik edecektir" $(\bar{x}=2,62)$, "lojistik köyler, ilimizdeki ürünlerin medyatik tanıtımını sağlayacaktır" $(\bar{x}=2,61)$ ve "lojistik köyler KOBİ niteliğindeki işletmelere dezavantaj oluşturacaktır" $(\bar{x}=2,25)$ olarak belirlenmiştir. Tüm önermeler için genel aritmetik ortalama ise $(\bar{x}=2,91)$ olarak saptanmıştır. Araştırmaya dahil edilen önermelerin aralıkların eşit olduğu varsayılmış, ortalama puan aralığ1 0,80 (En Yüksek Değer-En Düşük Değer)/5) olarak hesaplanmıştır. Her bir yargıya karşılık gelen puan aralıkları; "hiç katılmıyorum" $(1,00-$ 1,80), "katılmiyorum" (1,81-2,60), "k1smen katılıyorum" (2,61-3,40), "katılıyorum", (3,41$4,20)$ ve "tamamen katılıyorum"(4,21-5.00) olarak kodlanmıştır. Bu kodlama sonuçları göstermektedir ki Karabük ilindeki üretim işletmeleri yöneticileri lojistik köyler hakkında kısmi bilgiye $(\bar{x}=2,91)$ sahip bulunmaktadır.

Tablo 3'te üretim işletmeleri yöneticilerin lojistik köy algılarının demografik özelliklerine(cinsiyet, yaş, eğitim durumu) göre anlamlı bir farklılaşma gösterip göstermediğini belirlemek amacıyla; iki değişkenli gruplar (cinsiyet) için yapılan "Bağımsız Örneklem t-Testi"; ikiden fazla olan değişkenli gruplar (yaş, eğitim durumu) için yapılan "Bağımsız Örneklem Tek Yönlü Varyans Analizi (OneWay ANOVA)" sonuçları yer almaktadır.Ayrıca ikiden fazla olan gruplarda farklılığın hangi gruplar arasında gerçekleştiğini ortaya koymak amacıyla "Çoklu KarşılaştırmaTukey HSD-Analizi" sonuçlarına yer verilmiştir.

Tablo 3'te görüldüğ̈̈ üzere üretim işletmeleri yöneticilerinin lojistik köy algılarına ilişkin önermelerin, eğitim durumları açısından anlamlılık düzeyinde farklılık olduğu $(\mathrm{p}=0,000 ; \mathrm{p}<0,05)$ görülmektedir. Bu bağlamda yapılan Tukey testi sonucunda, lisans mezunu olanların, işletmelerin lojistik köy algılarına ilişkin önermelere ilköğretim, lise ve ön lisans mezunu olan kişilerden daha olumlu düzeyde katıldıkları saptanmıştır. Ayrıca lisansüstü mezunlarının da ilköğretim mezunu olanlardan daha olumlu düşündükleri tespit edilmiştir. Bu sonuçlar kapsamında "H3: Üretim işletmeleri yöneticilerinin eğitim durumuna göre lojistik köy alg1sı arasında anlamlı bir farklılık vardır." hipotezi kabul edilmiştir. 
Tablo 3. Üretim İşletmeleri Yöneticilerinin Lojistik Köy Algılarının Demografik Özelliklerine Göre Karşılaştırılması (n=108)

\begin{tabular}{|c|c|c|c|c|c|c|c|}
\hline Değişkenler & Gruplar & $\mathbf{n}$ & $\bar{X}$ & s.s. & $t / F$ & $\mathrm{p}$ & Tukey \\
\hline \multirow{2}{*}{ Cinsiyet } & Erkek & 93 & 2,93 & 1,30 & \multirow{2}{*}{0,394} & \multirow{2}{*}{0,532} & \\
\hline & Kadin & 15 & 2,77 & 1,16 & & & \\
\hline \multirow{4}{*}{ Yaş } & 31-35 yaş & 7 & 3,77 & 0,70 & \multirow{4}{*}{1,907} & \multirow{4}{*}{0,133} & \\
\hline & $36-40$ yaş & 33 & 2,83 & 1,34 & & & \\
\hline & $41-45$ yaş & 51 & 2,98 & 1,24 & & & \\
\hline & 46 ve üzeri & 17 & 2,46 & 1,32 & & & \\
\hline \multirow{6}{*}{ Eğitim Durumu } & İlkokul (a) & 16 & 1,90 & 1,07 & \multirow{6}{*}{6,067} & \multirow{6}{*}{$0,000^{*}$} & \multirow{6}{*}{$\begin{array}{c}e>a, c, d \\
f>a\end{array}$} \\
\hline & Ortaokul (b) & 13 & 3,05 & 1,12 & & & \\
\hline & Lise (c) & 43 & 2,81 & 1,21 & & & \\
\hline & Ön Lisans (d) & 8 & 2,52 & 1,35 & & & \\
\hline & Lisans (e) & 24 & 3,70 & 1,00 & & & \\
\hline & Lisansüstü (f) & 4 & 4,16 & 0,82 & & & \\
\hline
\end{tabular}

$*(\mathrm{p}<0,05)$

Tablo 4'deüretim işletmeleri yöneticilerin lojistik köy algılarının diğer özelliklerine(çalıştığı sektör, yöneticilik pozisyonu, lojistik köy bilgisi, lojistik köy yeri önerine katılım durumu) göre anlamlı bir farklılaşma sahip bulunup bulunmadığını tespit etmek amacıyla; iki değişkenli gruplar (lojistik köy bilgisi, lojistik köy yeri önerine katılım durumu) için yapılan "Bağımsız Örneklem t-Testi"; ikiden fazla olan değişkenli gruplar (çalıştı̆̆ı sektör, yöneticilik pozisyonu) için yapılan "Bağımsız Örneklem Tek Yönlü Varyans Analizi (One Way ANOVA)" sonuçları yer almaktadır.Ayrıca ikiden fazla olan gruplarda ortaya çıkan farklılığın hangi gruplar arasında gerçekleştiğini ortaya koymak amacıyla “Çoklu Karşılaştırma-Tukey HSDAnalizi" sonuçları kullanılmıştır.

Tablo 4'de görüldügü üzere üretim işletmeleri yöneticilerinin lojistik köy algılarına ilişkin önermelerin, yöneticinin çalıştığı sektöre göre farklılaştığı $(p=0,006$; $\mathrm{p}<0,05)$ göze çarpmaktadır. Yapılan Tukey testi sonucunda, demir ve çelik sektöründe faaliyet gösteren yöneticilerin $(\bar{x}=3,36)$ lojistik köylerinin kurulmasına, gida sektörü yöneticilerine $(\bar{x}=2,37)$ göre önemli buldukları yönünde değerlendirilebilir. Bu durum Karabük ilinin demir ve çelik sektöründe önde olmasıyla ilişkili bir durumdur. Bununla birlikte gıda üretiminde de son dönemlerde Safranbolu lokumu öne çıkan ve yurtiçi pazarda kendine yer bulan önemli bir üründür. Bu bağlamda, gida üretim işletmelerinin teşvik edilmesi, önem arz etmektedir. Bu tespitler çerçevesinde "H4:Üretim işletmeleri yöneticilerinin çalıştığı sektöre göre lojistik köy algısı arasında anlamlı bir farklılık vardır." hipotezi kabul edilmiştir. 
Tablo 4. Üretim İşletmeleri Yöneticilerinin Lojistik Köy Algılarının Diğer Özelliklerine Göre Karşılaştırılması (n=108)

\begin{tabular}{|c|c|c|c|c|c|c|c|}
\hline Değişkenler & Gruplar & $\mathrm{n}$ & $\bar{X}$ & s.s. & $t / F$ & $\mathrm{p}$ & Tukey \\
\hline \multirow{5}{*}{ Çalıştı̆̆g Sektör } & Demir ve Çelik (a) & 44 & 3,361 & 1,281 & \multirow{5}{*}{3,793} & \multirow{5}{*}{$0,006^{*}$} & \multirow{5}{*}{$a>d$} \\
\hline & Orman ve Ağaç (b) & 7 & 2,383 & 0,823 & & & \\
\hline & Tekstil (c) & 13 & 3,268 & 1,086 & & & \\
\hline & Gida (d) & 28 & 2,379 & 1,179 & & & \\
\hline & Diğer (e) & 16 & 2,546 & 1,332 & & & \\
\hline \multirow{3}{*}{$\begin{array}{l}\text { Yöneticilik } \\
\text { Pozisyonu }\end{array}$} & Üst kademe yönetici & 47 & 3,038 & 1,347 & \multirow{3}{*}{1,570} & \multirow{3}{*}{0,213} & \\
\hline & Orta kademe yönetici & 56 & 2,887 & 1,200 & & & \\
\hline & Alt kademe yönetici & 5 & 1,982 & 1,394 & & & \\
\hline \multirow{2}{*}{ Lojistik Köy Bilgisi } & Evet & 70 & 3,728 & 0,691 & \multirow{2}{*}{1,898} & \multirow{2}{*}{0,171} & \\
\hline & Hayır & 38 & 1,406 & 0,514 & & & \\
\hline \multirow{2}{*}{$\begin{array}{l}\text { Lojistik Köy Yeri } \\
\text { Önerisine Katılma }\end{array}$} & Evet & 77 & 3,314 & 1,089 & \multirow{2}{*}{0,646} & \multirow{2}{*}{0,423} & \\
\hline & Hayır & 31 & 1,909 & 1,180 & & & \\
\hline
\end{tabular}

$*(\mathrm{p}<0,05)$

Araştırma kapsamında yöneticilerden Karabük İli Lojistik Köy Seçim Alanı ile ilgili olarak "Karabük İli Eskipazar ilçesi Bayındır Köyü, lojistik köy kurulması için sizce uygun mudur?"sorusuna cevap aranmıştır.

Karabük Milli Emlak Müdürlüğü'nden alınan bilgiler doğrultusunda, gerek Kardemir A.Ş. ve gerek Organize Sanayi Bölgesine yakın olması nedeniyle ve ayrıca çevre illere bağlantı noktası da olabilecek bir konumda olan, lojistik köy için en uygun arazinin Karabük İli Eskipazar İlçesi Bayındır Köyü sınırları içinde yer alan 275 hektarlık bir arazi $\left(52,352 \mathrm{~km}^{2}\right.$ si hazine taşınmazı olup geri kalan arazinin bir bölümü mera ve bir kısmı da özel şahıs arazisi) olduğu tespit edilmiştir.Bu arazi, konumu itibariyle, Karabük-Ankara, Karabük-Çerkeş karayolu bağlantı noktasında ve KarabükEskipazar-Çerkeş-Kurşunlu-Ankara hattı demiryolu bağlantısında yer almaktadır. Eskipazar ilçe merkezine $12 \mathrm{~km}$ ve Karabük il merkezine $45 \mathrm{~km}$ uzaklıktadır.

Lojistik köyler için gerekli olan arazinin en az 250 hektar büyüklüğünde düz bir arazi olması yanında, karayolu, demiryolu güzergâhlarına ve mümkünse hava ve deniz yoluna yakın bir noktada bulunması gerekmektedir. Araştırma kapsamında önerilen lojistik köy yeri arazisi, kent merkezine en uygun mesafededir. Ayrica Karabük'te mevcut demiryolu bağlantısı güney-kuzeybatı doğrultusunda geçmekte olması yer tespitinde önemli bir noktadır (Resim 1).

Araştırmaya katılan 108 katılımcıdan 77 tanesi $(\% 71,3)$ önerilen arazinin lojistik köy kurulumu için uygun olduğunu ifade etmişlerdir. 


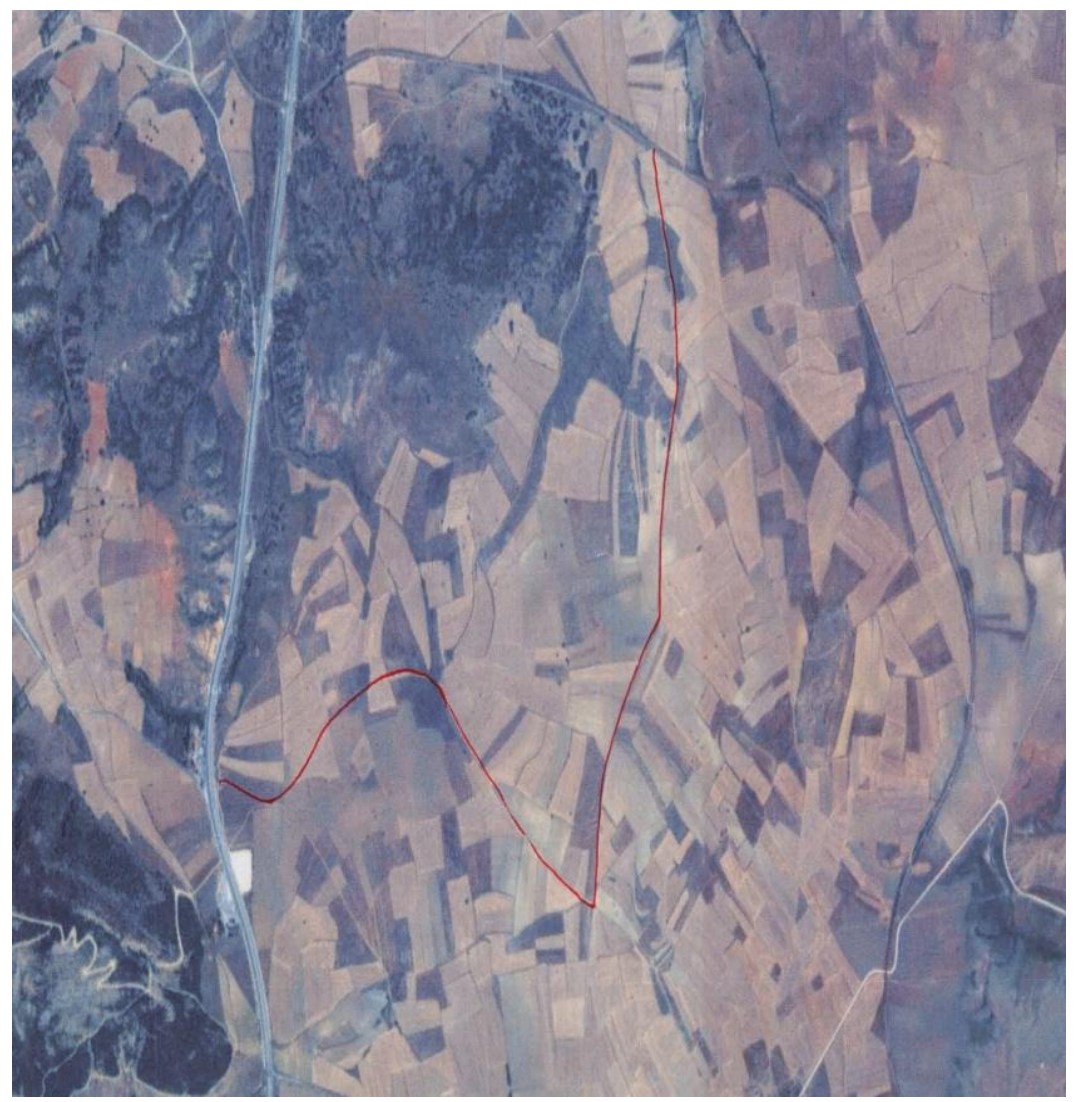

Resim 1. Karabük Lojistik Köy Yeri

Araştırma bulguları çerçevesinde araştırmada test edilmesi öngörülen hipotezlerinin kabul veya kabul edilmeme durumlarına ilişkin genel tespitler kapsamında; "H3: Üretim işletmeleri yöneticilerinin eğitim durumuna göre lojistik köy algısı arasında anlamlı bir farklılık vardır." ve " H4: Üretim işletmeleri yöneticilerinin çalıştığı sektöre göre lojistik köy algısı arasında anlamlı bir farklılık vardır." hipotezleri kabul edilmiştir. " H1: Üretim işletmeleri yöneticilerinin cinsiyetine göre lojistik köy algısı arasında anlamlı bir farklılık vardır.", " H2: Üretim işletmeleri yöneticilerinin yaşına göre lojistik köy algısı arasında anlamlı bir farklılık vardır." ve "H5: Üretim işletmeleri yöneticilerinin yöneticilik pozisyonuna göre lojistik köy algısı arasında anlamlı bir farklılık vardır." hipotezleri kabul edilmemiştir.

\section{SONUÇ}

Rekabetin artmasına bağlı olarak, ürünlerin müşterilere maksimum kalitede, hızlı ve güvenli bir şekilde ulaşmalarını sağlamak, işletmeler için son derece önemli hale gelmiştir. Pazarlama ve lojistikte yeni faaliyet alanlarının ortaya çıkması, tüm bu faaliyetlerin tek bir merkezde uygulanmasını sağlayan lojistik köylerin kurulmasını zorunlu kılar hale getirmiştir. Bu kapsamda ulusal ve uluslararası piyasada ürünlerin daha kaliteli, daha hızlı ve daha güvenli bir şekilde ulaşımını sağlayarak iç piyasada ve dünyada işletmelerin rekabet gücünü artıracak olan lojistik köyler Türkiye'nin dünya ölçeğinde rekabet gücünü artırarak Türk ürünlerinin dünyaya daha kolay, daha hızlı ve daha çok ulaşmasını sağlayabilecektir. 
Bu çalışmada henüz lojistik köy hizmetleri ile tanışmamış bir bölgedeki üretim işletmeleri yöneticilerinin lojistik köy algıları belirlenmeye çalışılmış ve lojistik köy algısının yöneticilerin demografik ve diğer özellikleri ile farklılaşıp farklılaşmadı̆̆ı araştırılmıştır. Ayrıca, Eskipazar ilçesi Bayındır Köyü bünyesinde lojistik köy kurulmasına yönelik düşünceleri öğrenilmiştir. Belirtilen amaçlar doğrultusunda Karabük Merkez ve Safranbolu ilçelerinde faaliyetlerini devam ettirmekte olan üretim işletmeleri yöneticilerinden anket tekniği kapsamında veriler elde edilmiştir.

Araştırmada yöneticilerin lojistik köy algılarına ilişkin görüşlerinin cinsiyet, yaş ve yönetim kademesi açısından eğitim durumları ve çalıştıkları sektör açısından farklılaştığı saptanmış ve bu kapsamda önerilen hipotezler kabul edilmiştir. Lisans mezunu yöneticilerin $(\bar{x}=3,70)$, lise $(\bar{x}=2,81)$, ön lisans $(\bar{x}=2,52)$ ve ilkokul $(\bar{x}=1,90)$ mezunlarına göre daha bilgili oldukları ve daha olumlu düşündükleri ortaya çıkmıştır. Ayrıca, demir ve çelik sektöründe faaliyet gösteren yöneticilerin $(\bar{x}=3,36)$ lojistik köylerinin kurulmasına, gıda sektörü yöneticilerine $(\bar{x}=2,37)$ göre önemli buldukları ve lojistik köylerin daha yararlı olacağına inandıkları tespit edilmiştir. Demir çelik işletmelerinin ihracat faaliyetlerinin çokluğu olumlu düşünmelerinde etkili olduğu söyleyebiliriz.

Saha çalışması neticesinde katılımcların çoğunluğu ile Karabük İli yer önerisi, Karabük İli Eskipazar ilçesi Bayındır Köyü sınırları içinde yer alan arazi olduğu tespit edilmiştir. Bayındır Köyü sınırları içinde yer alan arazi gerek ulaşım ağlarına yakın olması gerek şehir merkezine çok yakın olmaması ve çevre illere bağlantı noktasında olması sebebiyle uygun olduğu söylenebilir.Karabük'te kurulacak olan lojistik köyün özellikle şehir içinde ağır taşıtların yarattı̆̆ trafik sorununa çözüm getirerek şehir trafiğini rahatlatacağı ve yine şehirdeki hava kirliliğinin azalmasına yardımcı olabileceğini söyleyebiliriz. Bununla birlikte lojistik köy için Karabük'te özel sektör yöneticileri düzeyinde bilgi eksikliği bulunmakta ve desteklenmeleri önem arz etmektedir. Bu bağlamda, Karabük Üniversitesi'nden ve sivil toplum kuruluşlarından yararlanılabilir. Karabük ilinde lojistik bir köy kurulmasını zorunlu kılan sebepler şu şekilde sıralanabilir:

İlde çok zengin bir üretim profili bulunmaktadır. Demir çelik sektöründe faaliyet gösteren firmalar tarafından kütük, çelik, pik, yuvarlak demir, profil, köşebent, metal ve çelik döküm, blum, ray çeliği maden direği üretimi yapmaktadır.Çelik konstrüksiyon sektöründe faaliyet gösteren işletmeler tarafından çelik konstrüksiyon, fabrika binaları montajı, köprü imalatı, ambar, okul ve işyerleri, yangın merdiveni, kanopi, tank, tanker, silobas, silo, inşaat kalıbı vb. üretimleri yapılmaktadır.Döküm sektöründe firmalar tarafından pik metal döküm, hafif metal döküm, menhol kapakları, kanalizasyon kapakları, yol ızgaraları, heykel ve muhtelif döküm imalatı yapmaktadırlar. Makine imalat sektöründe faaliyet gösteren firmalar her türlü makine imalatı, yedek parça, bijon, redüktör, oto yedek parçaları, özel bağlantı elemanları vb. imalatı yapmaktadırlar. Hazır Giyim sektörü, markalı firmalar ve önemli markalara fason üretim yapan firmaların üretimlerinden oluşmaktadır. İlimiz bu sektörün sahip olduğu mevcut kapasite, altyapı imkânları, yetişmiş kalifiye eleman vb. kaynaklarla etkin bir organizasyonla hazır giyim bölgesi haline gelmesi mümkündür.Madencilik 
sektöründe mermer başta olmak üzere traverten, dolamit, bentonit, feldspat, kuvarsit, alçıtaşı, kireçtaşı, manganez yataklarına sahiptir. Ülkemizin dünyaca tanınmış birkaç mermer çeşidinden olan Rustik Yeşil Türkiye'de sadece ilimizde bulunmaktadır. Bölgemizde çıkan taşlar gerek iç piyasaya satılmakta, gerekse yurt dışına ihracatı yapılmaktadır.Orman ürünleri sektöründe ilimizin \%69'u ormanlarla kaplı olmasına rağmen bu potansiyel yeterince değerlendirilememiştir. Ormanlarımızda çam, köknar, kayın, meşe, gürgen gibi ağaçlar çoğunluktadır. Sektörde faaliyet gösteren firmalar kereste, kontrplak, parke vb. üretimlerini yapmaktadırlar.Çimento, hazır beton ve beton elemanları sektöründe faaliyette bulunan firmalarca çimento, karo, çini, beton direk, merdiven mozaik, kireç, briket, mıcır, kırmataş, kireçtaşı, beton parke taşı, bordür taşı, beton ve betonarme borular, cam mozaik, kent mobilyaları, hazır beton, kanalizasyon altyapı elemanları vb. imalatı yapılmaktadır.Gıda ürünleri imalat sektöründe; un ve unlu mamulleri üretimi, lokum, şekerleme, süt ve süt mamulleri üretimi, et ve et ürünleri üretimi yapılmaktadır (Gürbüz, 2009: 12-13).

Karabük İli 2002 yıllarında 18 Bin 720 ABD Doları olan ithalatını 2012 yılı itibariyle 482 Bin 827 ABD Doları seviyesine çıkartmış ve \%4 olan bölge payını da \%27 civarına yükseltmiştir. Karabük'te 2011 yılı verilerine göre 26 adet kayıtlı ithalatçı firma bulunmaktadır. İthalatçı firma başına 16 Milyon ABD Doları ithalat yapılmıştır. Kişi başına ithalat ise 1.902 ABD Doları'dır.

Karabük'ün ihracatında son yıllarda ciddi yükselişler olmuştur. İlin ihracatı 2000 yılında 10 Milyon ABD Doları seviyesinde bulunurken 2011 yılında rekor kırarak 224 Milyon ABD Doları seviyesine çıkmıştır. İlin bölge payı 2011-2012 yılları itibariyle \%33 seviyesinde bulunmaktadır. Karabük'te 2011 yılı verilerine göre 25 adet kayıtlı ihracatçı firma bulunmaktadır. İhracatçı firma başına yaklaşık 9 Milyon 860 Bin ABD Doları ihracat yapılmaktadır. Kişi başına düşen 1.020 ABD Doları ihracat ortalamasıyla il Türkiye'deki iller sıralamasında 17. sırada bulunmaktadır. Karabük'ün ihracatında da Zonguldak'ta olduğu gibi çelik sektörü baskındır. Çelik sektörünün ilin ihracatındaki payı yaklaşık \%89'dur. Çelik sektörünü \%5'lik katkısıyla savunma ve havacılık sanayi takip etmektedir. İlk beş sektörün il ihracatındaki toplam payı \%98,8'dir. 2012 yılında Karabük'ten 104 farklı ülkeye ihracat yapılmıştır. Bu ülkeler arasında il ihracatının yaklaşık \%26'sını gerçekleştiren Fas en fazla ihracat yapılan ülkedir. Fas'1, \%9'luk payıyla Yemen takip etmektedir. Suriye, Birleşik Arap Emirlikleri ve İran ilk beşteki diğer ülkelerdir. Bu beş ülkenin ihracat toplamı, il ihracatının \%58'ini oluşturmaktadır (http://bakka.gov.tr).

Türkiye Denizcilik İşletmeleri 2011 istatistik verilerine göre Türkiye Limanlarımızda elleçlenen toplam yük miktarı 363 milyon tondur ve Filyos Limanı için planlanan toplam yük kapasitesi yıllık 25 milyon tondur. Bu bağlamda bakıldığında da Filyos Liman Projesi Türkiye deniz taşımacılığı ihtiyacının \%6,9'unu karşılayacak olup deniz taşımacılığının gelişmesinde ve ürün çeşitliliğinin sağlanmasında da önemli katkılar sağlayacaktır. Projeye ilişkin olarak alınmış Bakanlar Kurulu Kararları ve projenin etki alanı nedeniyle de proje bölgesel kalkınma niteliği taşımaktadır. Proje kapsaminda yer alan Filyos Serbest Bölgesinin ve Filyos Endüstri Bölgesinin de faal olabilmesi öncelikle bölgedeki diğer büyük projelerin Filyos nehrinin sslahı ve Filyos 
Liman Projesi'nin yaşama geçirilmesi ile mümkün olabilecektir. Kamu sektörü yatırım projelerinin yanında çok sayıda özel sektör yatırımının da yer alacağı bölgesel nitelikli bu proje, Çaycuma ilçesinin sınırlarını aşan bir etki yaratacaktır. Projeyle birlikte Zonguldak, Bartın ve Karabük illerinin ekonomik yapısında önemli gelişmeler olacak, işsizlik ve göç azalacak ve yeni iş kolları açılacaktır. Bölge önemli bir sanayi ve lojistik üssü haline gelecektir. Filyos Liman Projesi, arka sahasındaki endüstri bölgesi ve serbest bölge, Zonguldak Çaycuma İlçesi Hisarönü (Filyos) beldesi sınırları içinde Filyos Irmağı'nın Karadeniz'e döküldüğü deltada planlanmıştır. Filyos Irmağı vadisinde geliştirilen bu proje Türkiye'de gerçekleştirilecek en büyük entegre yatırımlardan biri olacaktır. Bölge illerinin gelişimi ve geleceği tamamen bu projeye endekslenmiştir. Bu projenin hızlandırılarak tamamlanması yalnız bölge için değil ülke için de büyük bir kazanç sağlayacaktır. Filyos proje alanının su kaynağını (Filyos Irmağını) yan kolları olan Yenice, Devrek, Soğanlı ve Araç Çayları oluşturur. Filyos Irmağı havzası, Batı Karadeniz Bölgesi içerisinde $13.300 \quad \mathrm{~km}^{2}$ lik bir alanı kapsamaktadır. Proje alanı doğu-batı doğrultusunda 203 km, kuzey-güney doğrultusunda 120 km'dir. Yıllık 25 milyon ton kapasiteli Filyos limanın kuruluş yeri olarak Filyos Irmağı'nın doğu yakası seçilmiştir (Çetinkaya, 2012: 3-6).

Batı Karadeniz Bölgesi'nde Filyos Vadisi projesinin yapılacağı bölge denizyolu, demiryolu, karayolu ve havayolu ulaşım imkânları bulunmaktadır. Ulaşım ağının çeşitliliği açısından güçlü bir bölge olmasına rağmen, bölgede bunların kullanımları yeterli düzeyde değildir. Bölgenin, lojistikte Samsun ve İstanbul Limanları ile rekabet edebilir hale gelebilmesi için mevcut ulaşım ağlarının geliştirilip, birbirleri arasındaki geçişlerin sağlanması şarttır. Ancak bunlar gerçekleştirilirse bölgenin coğrafi konumu ve sahip olduğu ulaşım çeşitliliği bir anlam ifade edecektir. Bu sebeple geliştirilen projenin yanında diğer ulaşım ağlarında yapılan yatırımlarla bölge lojistik anlamda çok önemli bir yere sahip olacaktır. Filyos Vadisi projesi arazisinin hemen yanında (bölgenin güneybatı sınırına cepheli) Zonguldak-Karabük-Irmak demiryolu bulunmaktadır. Zonguldak- Karabük demiryolu bağlantısı önemli bir potansiyel taşımaktadır. Ağın modernleştirmesi 2010 yılı AB Katılım Ortaklı̆̆ı Mali Destek Programına alınmış ve 2012 yılında proje için sözleşme imzalanmıştır. AB tarafından finanse edilen Irmak-Karabük-Zonguldak Hattının Rehabilitasyonu ile Sinyalizasyon ve Telekomünikasyon Sistemlerinin Kurulumu (IKZ) Projesi Türkiye'deki en büyük hibe projesidir. Avrupa Birliği ile Türkiye'nin ortaklaşa finanse ettiği Türkiye'deki en büyük proje olma özelliğindeki IKZ Projesi yaklaşık 227 milyon avroya mal olacaktır. IKZ Projesinde, sözleşme bedelinin \%85'i AB'den sağlanan hibe ile \%15'i ise Türkiye katkısı olarak Avrupa Yatırım Bankasından sağlanan kredi ile karşılanacaktır. Yüklenici firmalar 25 Ocak 2012 tarihinde çalışmalarına başlamıştır. Projenin inşaat süresi 48 ay olup, Ülkü-Karabük-Zonguldak arası ilk 24 aylık sürede tamamlanması öngörülmüştür (Çetinkaya, 2012: 3-6).

Karabük'te lojistik köy kurulması ile özellikle işletmelerin, pazarlama süreçlerinden biri olan taşıma maliyetleri ve dolayısıyla ürün maliyetleri düşecek, yeni yatırımların yapılmasını sağlayarak özellikle göçü önleyerek istihdam yaratacaktır. İçinde bulunduğumuz yüzyılda rekabet göz ardı edilemez bir noktada önem 
taşımaktadır. Karabük'te yer alan işletmelerin üretimi için gerekli olan hammadde tedarikinde taşıma maliyetlerinin yüksek olması, üretilen ürünlerin satış ve pazarlanması noktasında yine taşıma maliyetlerinin yüksek olması nedeniyle, bu şartlarda rakip ürünlerle rekabet edilemez düşüncesiyle yeni yatırımlar yapilamamaktadır.

Lojistik köylerde dağıtımın tek merkezden olması, tüm lojistik faaliyetlerin tek merkezden gerçekleştirilmesi maliyetleri düşüreceğinden işletmeler de bu anlamda rekabet edebilir düzeye gelecekler ve yeni yatırımlar yapılabilirliği sağlanacaktır. Gerek lojistik köyün yaratacağ istihdam ile Karabük'te işsizlik büyük ölçüde azalacaktır.

\section{Araştırmanın Sınırlılıkları}

Bu araştırma Karabük ili içerisindeki üretim işletmeleri yöneticilerinin görüşleri araştırma kapsamında geliştirilen lojistik köy algısı ölçeğinde yer verilen ifadelerle sınırlıdır. Çalışma, Karabük'te lojistik köy alanında araştırma yapmak isteyen akademisyenlerin,bürokratlar, sivil toplum kuruluşları ve bölge halkı açısından önem arz etmektedir Gelecekte yapılacak benzer çalışmalarda kamu sektörü yöneticileri, STK yöneticileri ve akademisyenler üzerinde yapılacak benzer araştırmalarda bu çalışmada geliştirilen ölçek kullanılarak yeni araştırmalar yapılması, yeni öngörülerin oluşturulması Karabük ilinde lojistik köy kurulma sürecini hızlandırabilir.

\section{KAYNAKÇA}

Aydın, G. ve Ögüt, K. S. (2008). Lojistik Köy Nedir, 2. Uluslararası Demiryolu Sempozyumu, İstanbul: TCDD, 1439-1448.

Bezirci, M. ve Oktay A. (2011). Lojistik Köylerin İşletmelere Sağladığı Maliyet Avantajları. Trakya Üniversitesi Sosyal Bilimler Dergisi, 13(1): 292-307.

Çetinkaya, M. (2012). Filyos Vadisi Projesi. <http://bakka.gov.tr/assets/raporlar/FilyosVadisi.pdf> Erişim Tarihi: 01 Ocak 2016.

Elgün, N. M. (2011). Ulusal ve Uluslararası Taşıma ve Ticarette Lojistik Köylerin Yapılanma Esasları ve Uygun Kuruluş Yeri Seçimi.Afyon Kocatepe Üniversitesi İ.I.B.F. Dergisi, 13(2), 203-226.

Elitaş, C. ve Elgün N. M. (2011). Yerel, Ulusal ve Uluslararası Taşıma ve Ticaret Açısından Lojistik Köy Merkezlerinin Seçiminde Bir Model Önerisi.Celal Bayar Üniversitesi Sosyal Bilimler Dergisi, 9(2), 630-645.

Erdil, M. (2010) Ekonomik Kalkınma Stratejisi Olarak Lojistik Köyler, Yayınlanmamış Yüksek Lisans Tezi, Marmara Üniversitesi Sosyal Bilimler Enstitüsü İşletme Ana Bilim Dalı: İstanbul.

Gürbüz, A. (2009).Yeni Teşvik Uygulamasında Fırsatlar Kenti Karabük. Karabük.

$<$ http://bakka.gov.tr/site/sayfa/29/bolgemiz/\#.> Erişim Tarihi: 10 Ekim 2014.

<http://www.karabukyatirim.com/s/genel-bilgiler-.html> Erişim Tarihi: 10 Ekim 2014.

$<$ http://www.kto.org.tr/d/file/konyada-lojistik-sektoru---mayis-2013.pdf> Erişim Tarihi: 01 Kasım 2015. 
A. Gürbüz, N. Ayaz, S. Kebeci/ Karabük Üniversitesi Sosyal Bilimler Enstitüsü Dergisi, Özel Sayı 2, 2016, 1-19

Kılıç, Y. (2009). Gelişmekte olan Ülkelerde Sürdürülebilir Kalkınma Açısından Lojistik Köyler: Türkiye Örneği.Yayınlanmamış Yüksek Lisans Tezi. Süleyman Demirel Üniversitesi, İktisadi ve İdari Bilimler Fakültesi, İşletme Bölümü:Isparta.

Koldemir, B. ve Kudu, E. (2015).Liman-lojistik merkez etkileşim süreci: Kocaeli örneği. <http://ulk2015.deu.edu.tr/0017.pdf> Erişim Tarihi: 01 Ocak 2016.

Özgen, H. (2011).Samsun Modern Lojistik Köyünün 21.yy Ekonomisine Entegrasyonu: Gelişen ve Değişen Şartlara Uyumu Stratejik Yaklaşımlar, Samsun.

Paksoy, T. (2011).Lojistik Kümelenme ve Lojistik Köyler, Konya.

Üzülmez, H. (2008). Sadece Sanayiciye Değil, Şehrimize Katkı Sağlayacak.Lonca Dergisi, Konya Sanayi Odası,(30), Konya.

Vural, C. A. ve Tuna, O. (2014). Lojistik Merkezlerde Müşteri Beklentileri: Endüstriyel Pazarlama Yaklaşımı. 19. Ulusal Pazarlama Kongresi Bildiri Kitabı (s.3-14), Gaziantep. 